مطالعه تاثير فسفر بر گلدهى و برخى صفات رويشى كل آهار (Zinnia sp) در محيط حاوى ورمى

\author{
كميوست \\ رحمانى فاطمة"، محمدى اميرعلى، مرادى حسين \\ كروه علوم باغبانى دانشخاه علوم كشاورزى و منابع طبيعى سارى، سارى، ايران. \\ \ fatemehrahmani60@gmail.com

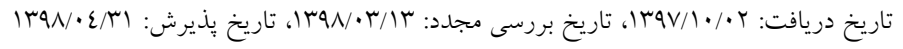

جكيده

گل آهار به علت داشتن طول دوره گلدهى طولانى و استفاده بهصورت شاخه بريدنى و در فضاى باز، از گياهان زينتى ثير كاربرد

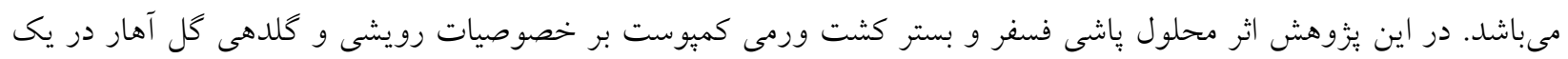

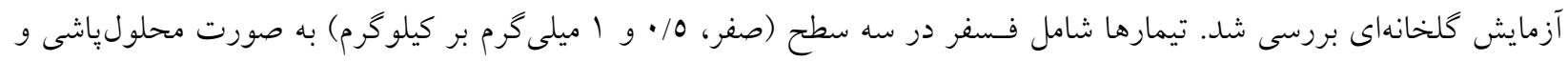

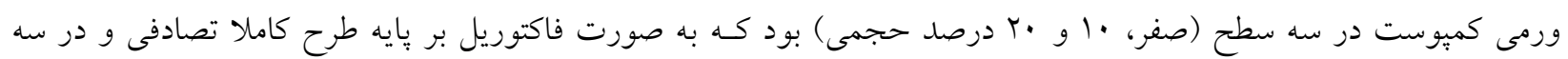

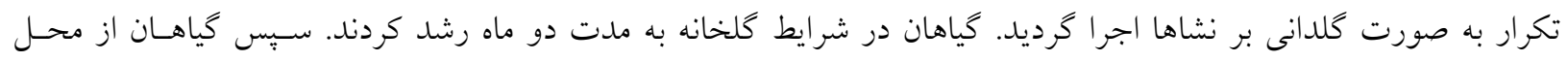

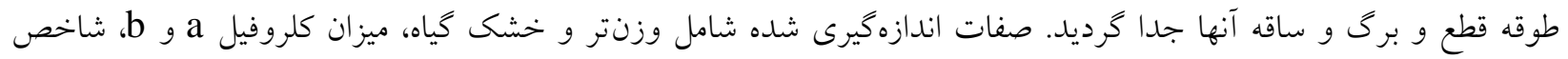
كلروفيل، طول ريشه، ساقه كل دهنده و قطر كل بوده است. نتايج نشان داد استفاده از فسفر و ورمى كميوست با درصدهاى بالاتر اثر كذارى معنى دارى در تمامى صفات مورد بررسى نسبت به شاهد داشت. به طوريكه بيشترين قطر كل به ميزان 0/0 سانتى متر و

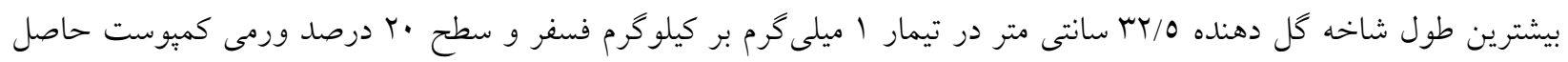

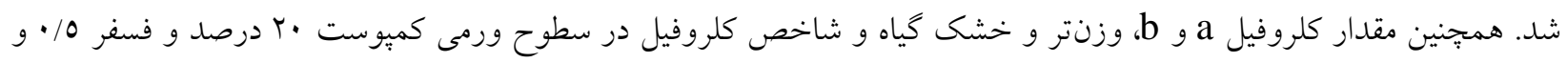

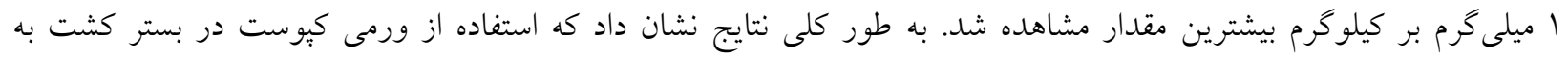
همراه محلول ياشى فسفر موجب بهبود صفات رويشى و زايشى در گل آهار مى گردد. كلمات كليدى: بستر كشت، قطر گل، عملكرد، كلروفيل، كلخانه

مقدمه

است. آهار ازجمله گل هاى فصل تابستان است كه به دليل

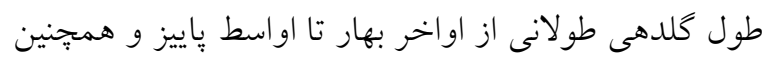

كل آهار (Zinnia sp) يكى ازگل هاى زينتى خانواده

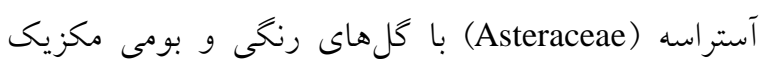


گياهى است كه داراى نقش كاتاليزورى در واكنشهاى بيوشيميايى در كياهان مىباشد. همجنين اين عنصر جزء مهمى از DNA و بخش مهمى از واحد انرزى كياهان

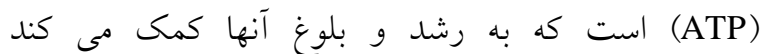

.(Ahmad et al.2017)

در آزمايشى مشاهده شد اضافه كردن ورمى كميوست به

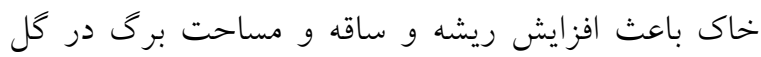
هميشه بهار شد (Atiyeh et al.2004). در مطالعاتى نشان داده شده مصرف ورمى كميوست باعث افزايش خصوصيات زايشى در سنبل آبى و كل بنفشه نسبت به به

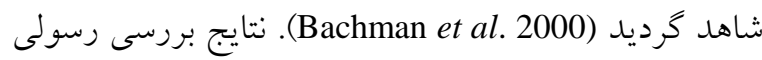

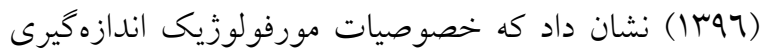
شده تابع نوع ورمى كميوست مى باشد. همجنين عزيزى و همكاران (IrMV) كزارش كردند كه استفاده از ورمى كميوست در افزايش عملكرد كيفى بابونه نقش داشته است. بررسى ها نشان مى دهل ورمى كميوست با افزايش ظرفيت نخهدارى آب، تامين عناصر غذايى و توليد هورمون هاى

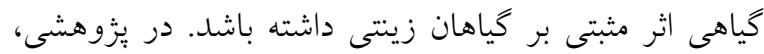

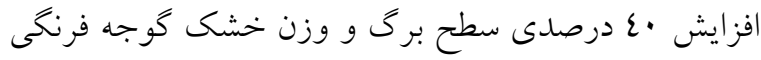

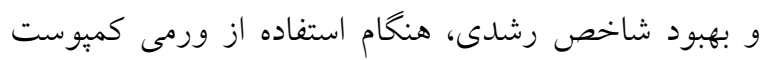

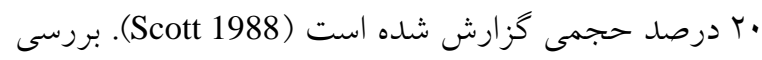
امجزى و حميد يور (ع (1) نشان داد كه بيشترين مقدار يارامترهاى رويشى مربوط به تيمار ورمى كميوست بود كه اختلاف معنى دارى نسبت به بقيه تيمارها و هم جنين تيمار شاهد داشت. در آزمايش انجام شده جهت افزايش عملكرد كياه برازمبل (Perovskia) مصرف همزمان كود هاى نيتروزن و فسفر باعث افزايش عملكرد در اين كياه شده است (جعفرى عqب1). نتايج بررسى نعمتى و همكاران

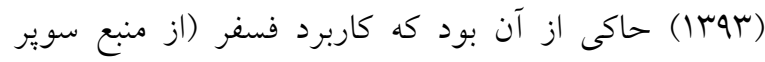
فسفات ترييل) باعث افزايش عملكرد و اسانس در گياه زوفا شده است. استفاده از محلول پپاشى (Hyssopus officinalis) فسفر در سطح 0 • • ميلى مولار باعث كاهش صفات
تحمل به خشكى و گرماى زياد داراى ارزش بالايى در فضاى سبز است. با توجه به اهميـت كـل و كرياهـان

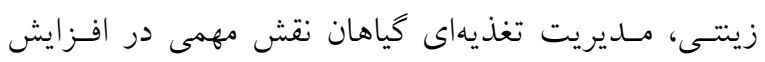

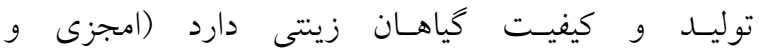
همكاران (1) ). يكى از راهكارهاى مهم براى رسيدن به

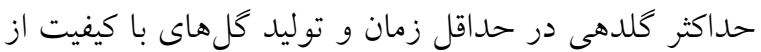
مواد آلى و معدنى بهعنوان بستر كاشت كياهان زينتى مى -

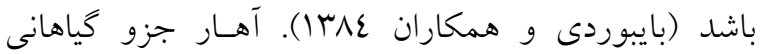
است كه در فضاى سبز كاربرد زيادى دارد و همهساله قسمت اعظمى از فضاى سبز به كاشت اين گياه اختصاص

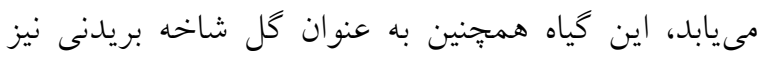

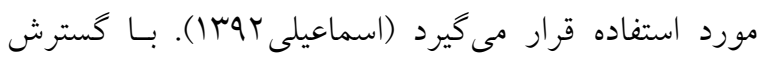

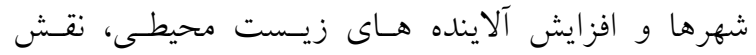
كياهان در فضاهاى شهرى هر روز افـزيش مسى يابـــ.

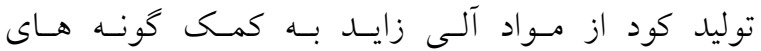

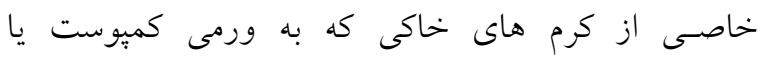
كميوست كرمى معروف است در كشورهاى مختلف جهان

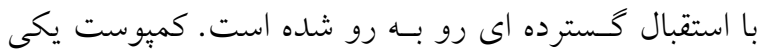
از مهمترين مواد آلى بوده كه به خاطر مزاياى متعدد آن

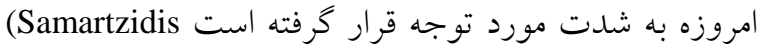
et al 2005) كياهان زينتى دو مشكل عمد در كشور در مقايسه با ساير كشورها مىباشد كه مىتوان با مطلوب سازى شرايط توليد و همجنين استفاده از تنظيم كنند هاى رشد بر اين مشكلات غلبه كرد (Hashem abadi et al 2000). از مهمترين إنسين فاكتورهاى مؤثر بر كيفيت و طـول عمـــيس از برداشت اين

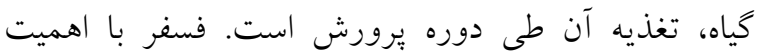
ترين عنصر در رشد كياه مىباشد و يس از نيتروزن مهم

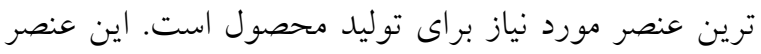
در همه فرايندهاى بيوشيميايى، واكنش هاى انتقال انرزى و

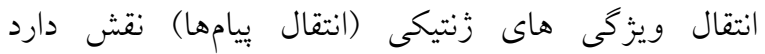
(Kumar et al. 2009). فسفر عنصر كليدى در ساختار 
انجام مى گرديد. جمع آورى و ثبت اطلاعات به صورت

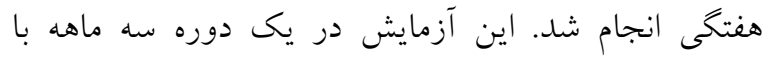

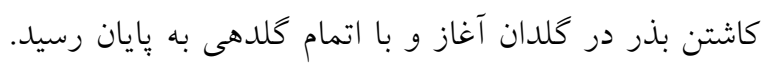

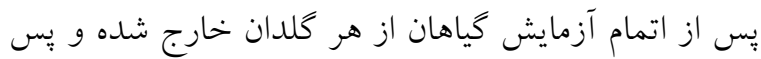

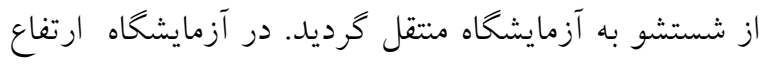
كياه، فاكتورهاى رشدى گياه مانند طول ريشه، وزنتر ريشه

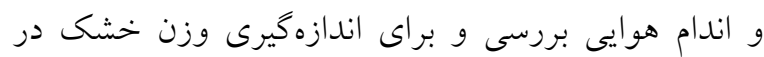

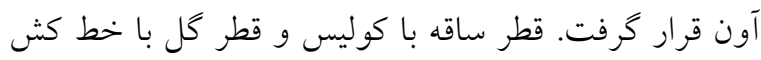

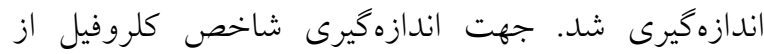
دستخاه كلروفيلمتر (SPAD 502 Plus) استفاده كرديد. براى تعيين غلظت مجموع كلروفيل a و 10 • كرم از مادهى

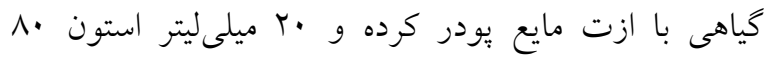

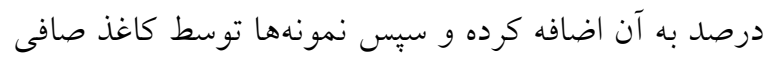
صاف شدند و حجم آن توسط استون به •0 ميلى ليتر رسيد. نمونه آماده شده را در سانتريوز ل..7 دور به مدت ل1 دقيقه قرار داده و در ادامه محلول را از كاغذ صافى رد كرده و در اسبكتوفوتومتر با طول موجهاى ساب7 نانومتر (كلروفيل a و a محاسبه شد (Lichtenthaler, 1987). بر اساس اعداد خوانده شده توسط دستخاه اسيكتوفتومتر غلظت مجموع كلروفيل بر اساس ميكرو گرم بر وزنتر برى بيان شد.

1) chla = 12/25 A663/2 - 2.79 A646.8

2) $\mathrm{chlb}=21 / 21 \mathrm{~A} 646 / 8-5 / 1 \mathrm{~A} 663.2$
مطلوب در گياه شمعدانى شد درحالى كه كاهش سطح تا / • ميلى مولار باعث كاهش ارتفاع و بهبود ساير صفات كمى و كيفى در اين كياه شده است (ميركوهى، سوبـإ). باتوجه به كاربرد فراوان كل آهار در فضاى سبز و و از آنجا دئ كه بهره گيرى از مواد آلى در كنار مواد شيميايى مى تواند بر رشد كياه موثر باشد، اين يزوهش با هدف بررسى اثر

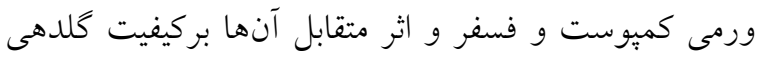
و صفات رويشى مطلوب انجام مى گيرد.

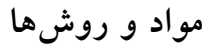

آزمايش به صورت فاكتوريل بر پايه طرح كاملا تصادفى با

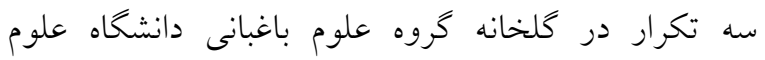
كشاورزى و منابع طبيعى سارى در سال فاكتور اول شامل ورمى كميوست با نسبتهاى ( (V1=)

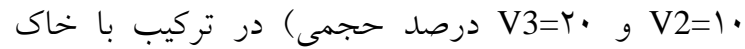
(جدول () بوده و فاكتور دوم در اين آزمايش محلول پِشى

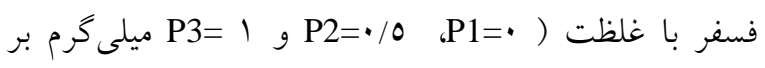
كيلو گرم) بوده است. يس از ضدعفونى نمودن بذرها در

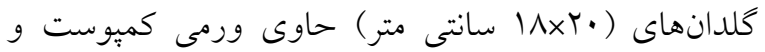
خاى كاشته شدند و در محيط گلخانه نخهدارى گرديدند (شكل (). تيمار فسفر با نسبت مشخص شده به بستر اضافه

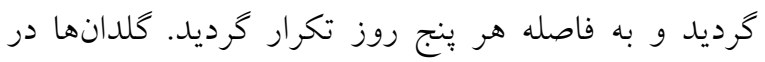

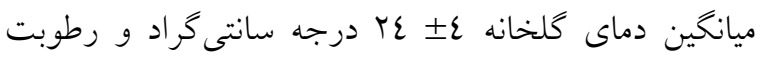
نسبى •V نخهدارى شدند و زمان خشك بودن بستر آبيارى

جدول ا- خصوصيات بستر كشت مورد استفاده

Table 1. Characterics of the cultivation medium

\begin{tabular}{|c|c|c|c|c|c|c|c|c|}
\hline بتاسيم قابل & $\begin{array}{l}\text { فسفر قابل } \\
\text { (p.p.m) }\end{array}$ & درصد ازت & حرصد مواد & $\begin{array}{c}\text { هدايت } \\
\text { الكتريكى } \\
\text { EC x } 10^{-3}\end{array}$ & $\begin{array}{l}\text { اسيديته كل } \\
\text { اشباع } \\
\text { pH }\end{array}$ & $\begin{array}{c}\text { درصد ماده } \\
\text { آلى } \\
\text { O.M\% }\end{array}$ & $\begin{array}{l}\text { كربن آلى } \\
\text { O.C\% }\end{array}$ & بافت خاك \\
\hline$\Delta G$ & $1 \pi$ & $1 / 1$ & $r N / \Delta$ &.$/ 9$ & $8 / \mathrm{V} \Lambda$ & $19 / \wedge r$ & $11 / 0$ & شنى- لومى \\
\hline
\end{tabular}




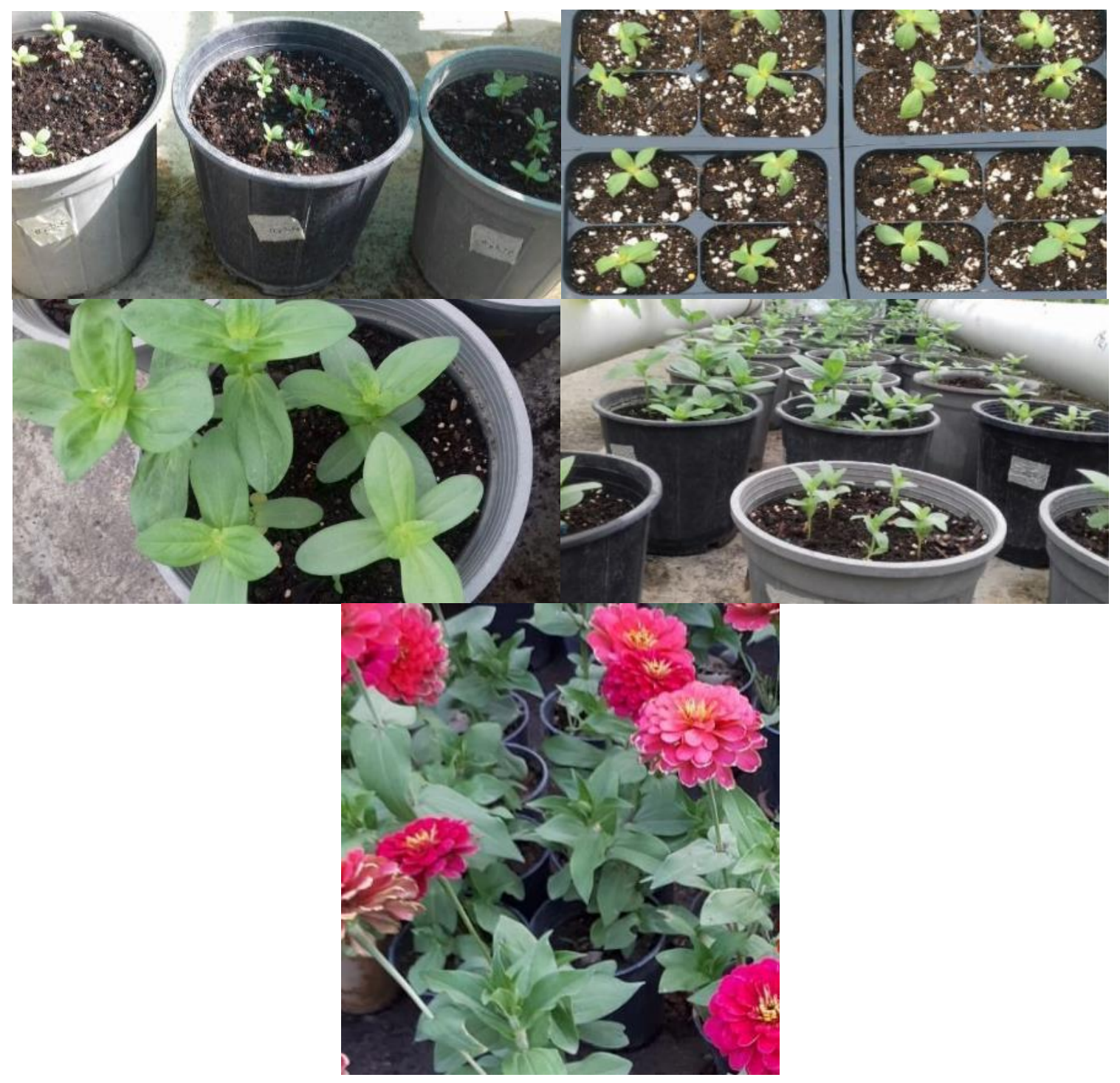

شكل ا- نحوه استقرار نشا گل آهار در گلدان (A) و گلدهى (B) در گلدان حاوى ورمى كميوست قبل از اعمال تيمارهاى فسفر

Fig 1. The method of cultivation and establishment of Zinnia plantlets in pots containing vermicopost (A) and flowering (B) before phosphorus treatments

كيلوگرم فسفر به مقدار 1/17 1 سانتى متر بدست آمد كه با

ساير تيمارها اختلاف معنى دارى داشت. همجنين كمترين

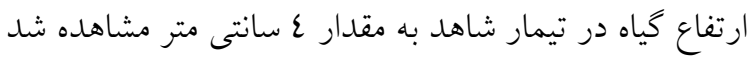
(a-r (a) (a)

r. در صفت عرض برگ بستر حاوى ورمى كميوست

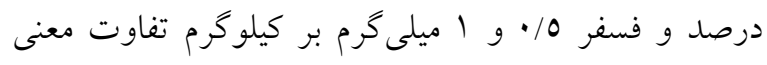

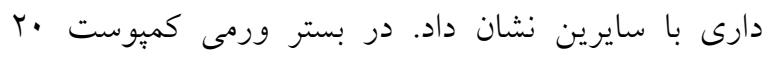

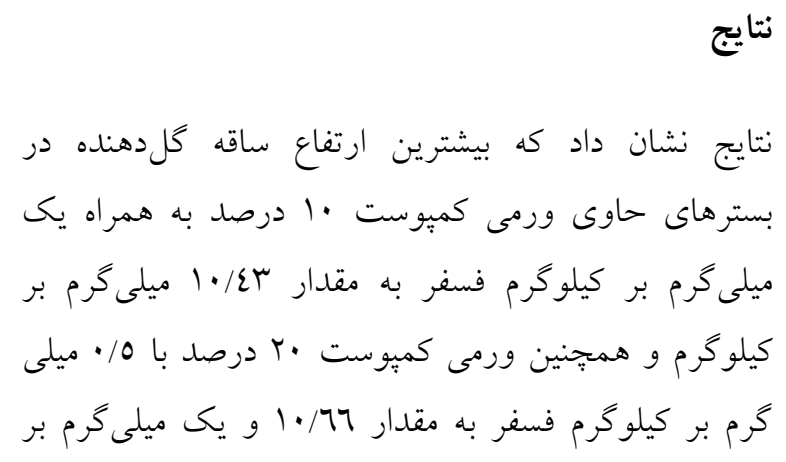


همجنين ورمى كميوست · 1 درصد با فسفر يك ميلى گرم بر كيلو گرم تفاوت معنى دارى نداشت. كمترين مقدار شاخص كلروفيل در تيمار شاهد به ميزان I/V حاصل شد (شكل (a-r با بررسى طول ريشه مشخص كرديد كه بيشترين طول ريشه در بستر ورمى كميوست ·r درصد به همراه فسفر 0 • • ميلى كرم بر كيلو گرم بدست آمد. به طوريكه در اين تيمار طول ريشه I/7T/ سانتى متر بود كه با سايرين تفاوت معنىدارى داشته است. كمترين طول ريشه در تيمار شاهد و بستر حاوى ورمى كميوست ·r درصد با فسفر صفر به ميزان

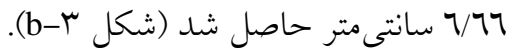
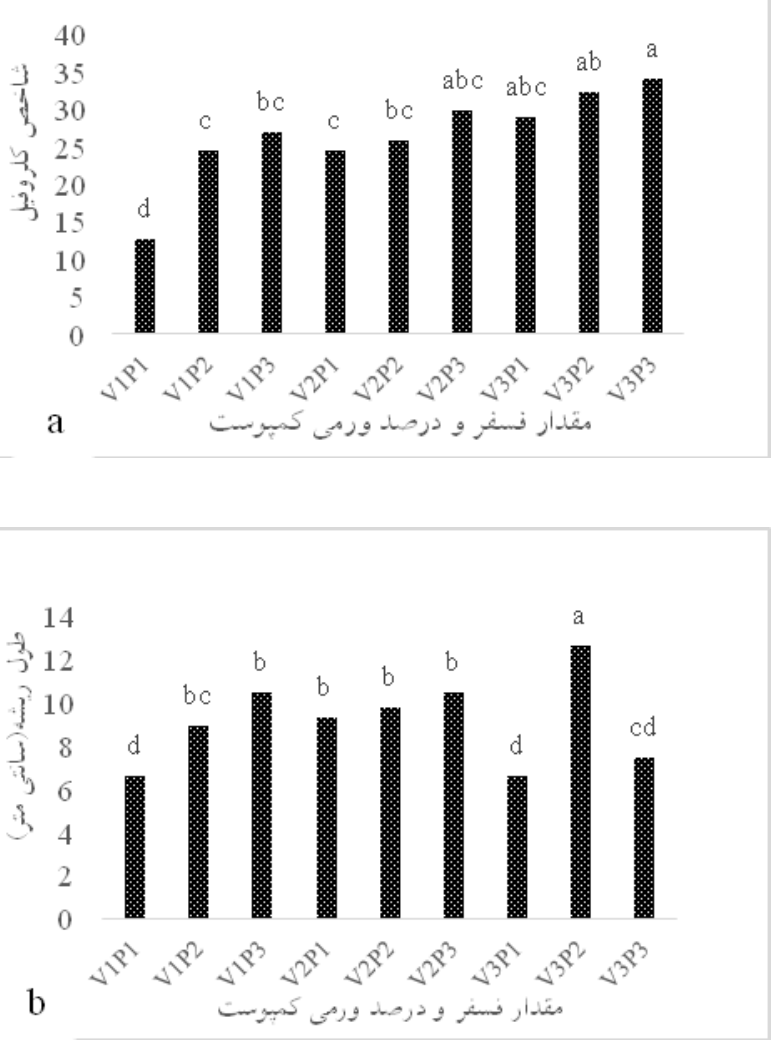

$$
\begin{aligned}
& \text { شكل r- شاخص كلروفيل (a) و طول ريشه (b) آهار تحت تاثير } \\
& \text { تيمار فسفر در بستر ورمى كميوست }
\end{aligned}
$$

Fig 3. Chlorophyl content (a) and root length (b) of Zinnia treated with different concentrations of phosphorus and vermicompost
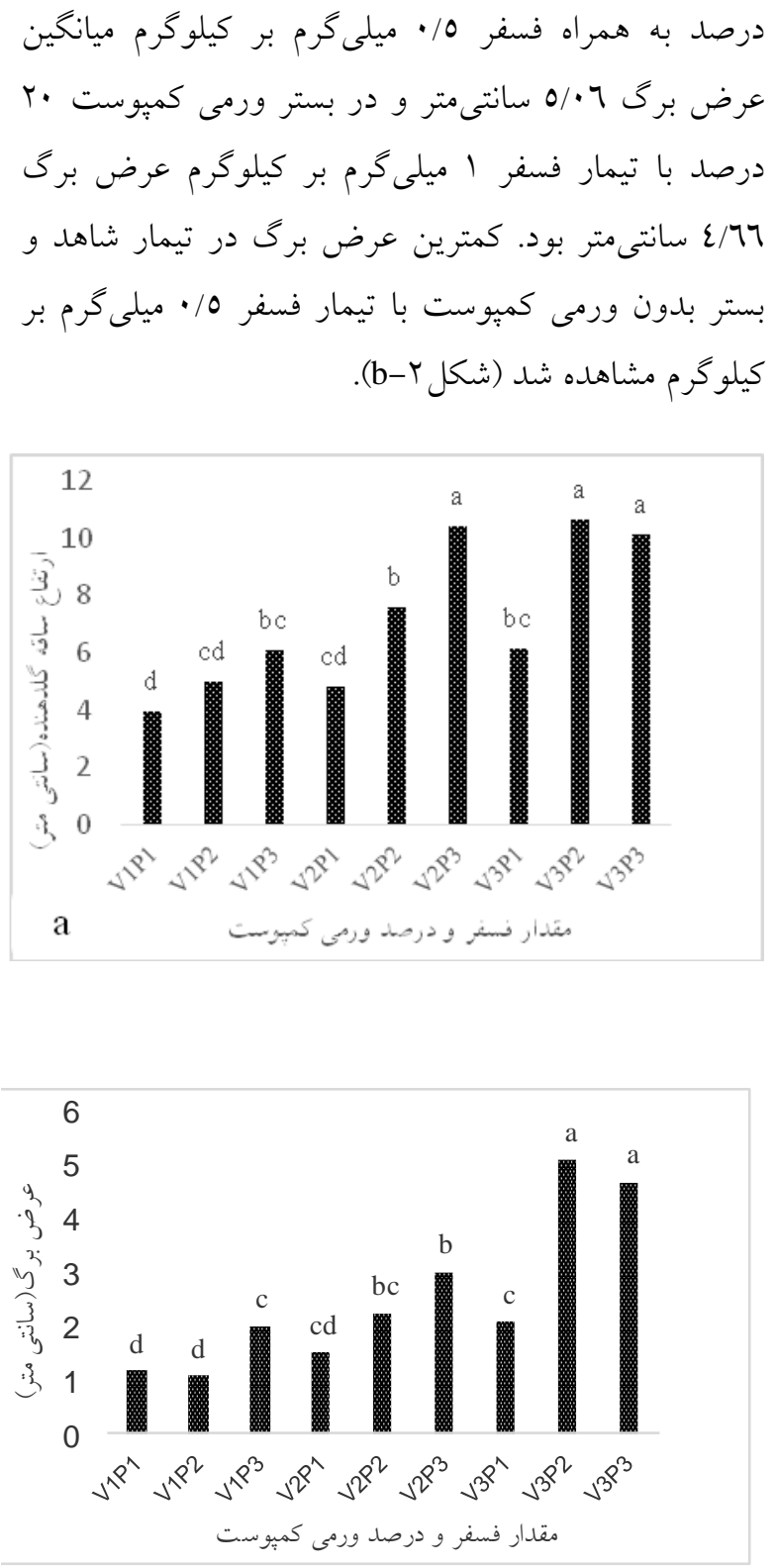

$$
\begin{aligned}
& \text { شكل r- ارتفاع ساقه گلدهنده (a) و عرض برگ (b) آهار تحت } \\
& \text { تاثير تيمار فسفر در بستر ورمى كميوست }
\end{aligned}
$$

Fig 2. Height of the flowering stem (a), width of the leaf (b) of Zinnia treated with different concentrations of phosphorus and vermicompost

بيشترين ميزان شاخص كلروفيل در بستر حاوى ورمى كميوست ·r برصد و فسفر يك ميلى گرم بر كيلو گرم به ميزان //عَ بدست آمد. اگرجّه اين مقدار با تيمارهاى ورمى كميوست ·T درصد به همراه فسفر سطح · و 10 • و 
سطح فسفر بيشترين مقادير مشاهده شد، كه با ساير تيمارها

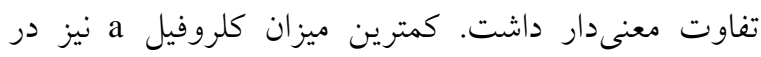

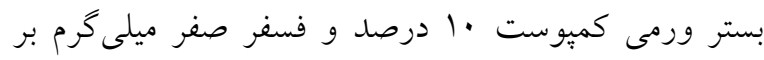

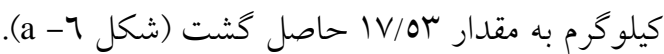
مقدار كلروفيل b در بستر ورمى كميوست •r درصد با

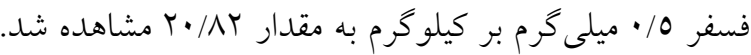

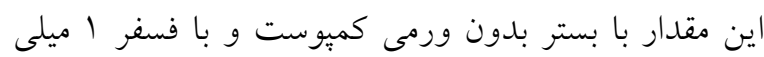

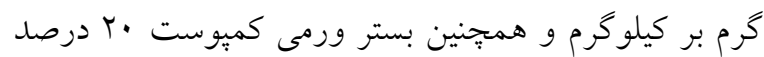
و فسفر صفر ميلى گرم بر كيلوگرم تفاوت معنى دار نداشت.

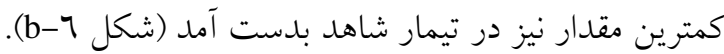
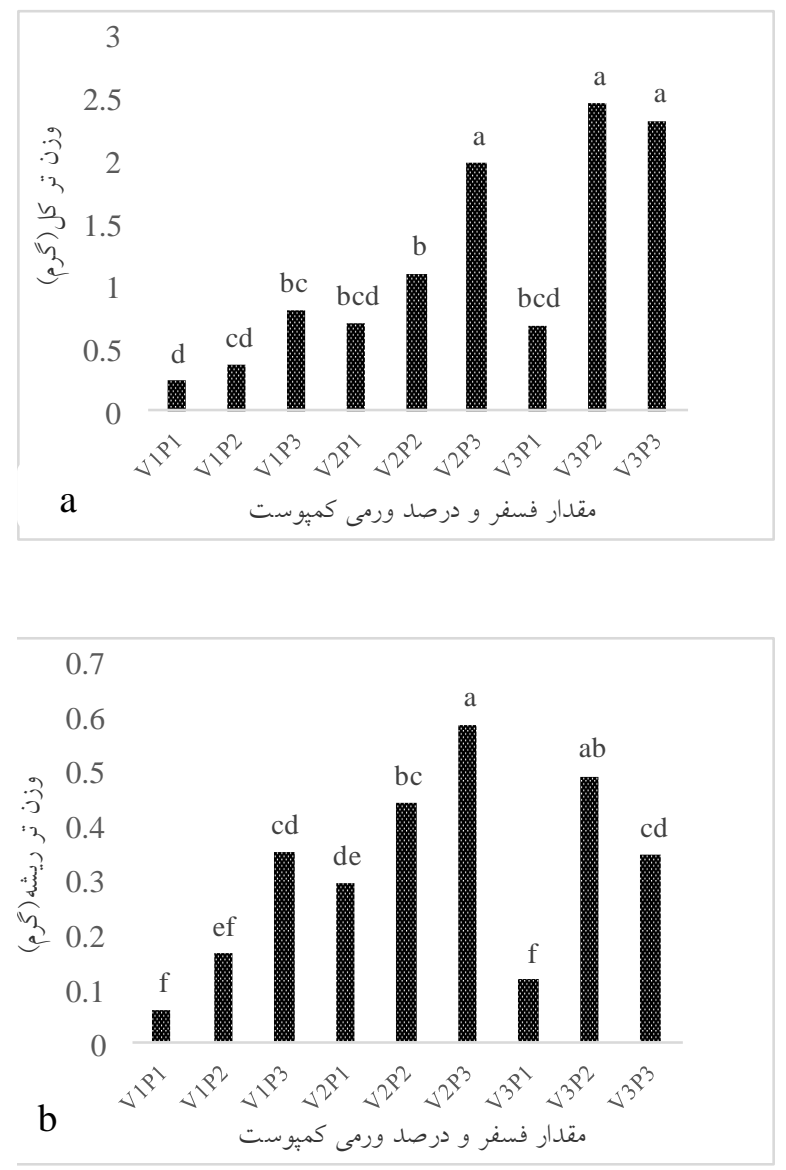

شكل ع- وزن تر كل كياه (a) و وزن تر ريشه(b) آهار تحت تاثير

$$
\text { تيمار فسفر در بستر ورمى كميوست ونت وزئ }
$$

Fig 4. Total plant fresh weigth (a) and root dry

weight (b) in Zinnia treated with different concentrations of phosphorus and vermicompost
بررسى وزنتر كل كياه نشان داد كه بيشترين وزن كياه در بسترهاى حاوى ورمى كميوست ·r درصد با فسفر

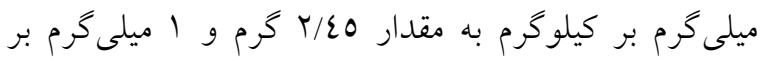

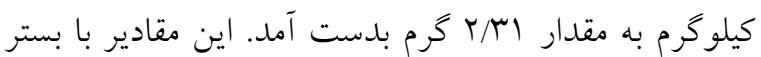
داراى ورمى كميوست ·ل درصد به همراه فسفر ا ميلى گرم بر كيلو گرم كه به ميزان 1/9V كرم بود، تفاوت معنىدارى نداشت. همجنين كمترين وزن كل در تيمار شاهد به مقدار

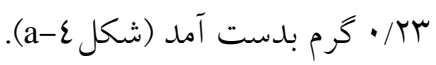
بررسى وزنتر ريشه نشان داد كه در بستر حاوى ورمى كميوست • ل درصد با تيمار فسفر ا ميلى گرم بر كيلوگرم

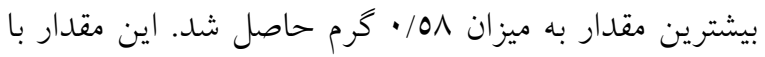

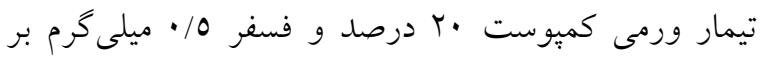

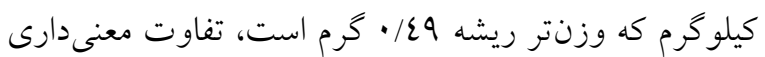
نداشت. كمترين وزنتر ريشه در تيمار شاهد با مقدار 7. كرم و در تيمار بستر حاوى ورمى كميوست ·r درصد و

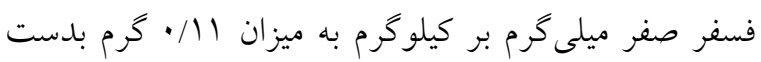

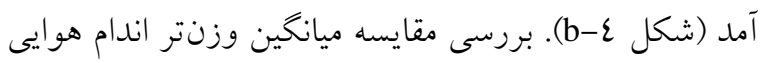
نشان داد كه بيشترين مقدار اين صفت در بستر ورمى

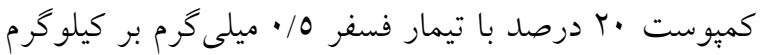

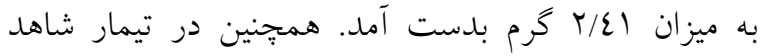

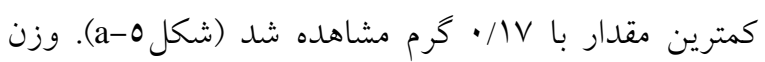

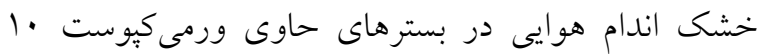

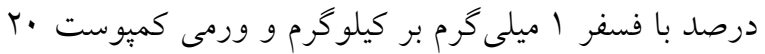
درصد با فسفر 10 • و ا ميلى گرم بر كيلوگرم نسبت به ساير تيمارها تفاوت معنىدارى داشت. مقادير به دست آمده در

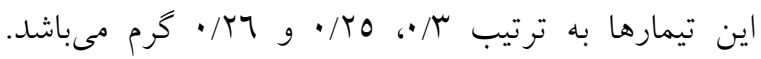
همجنين ميان ساير تيمارها تفاوت معنىدارى مشاهده نشد

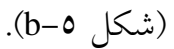
بررسى كلروفيل a كياه نشان داد كه ميزان كلروفيل در

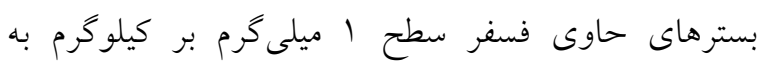
تنهايى و ورمى كميوست · ا درصد به همراه فسفر 0/ • و 1 ميلى گرم بر كيلوگرم و ورمى كميوست •r ب درصد در هر سه 
0/0 سانتىمتر مشاهده شد. اين مقدار با قطر گل حاصل از

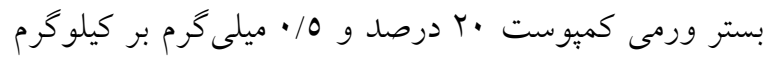
فسفر با اندازه 0/17 سانتى متر تفاوت معنىدارى نشان نداد. كمترين قطر كل در تيمار شاهد و فسفر 10 • و ا ميلى گرم

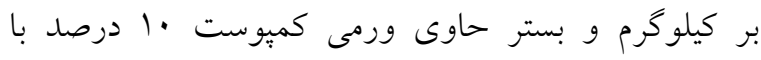
فسفر صفر بلدست آمد (شكل b-V).
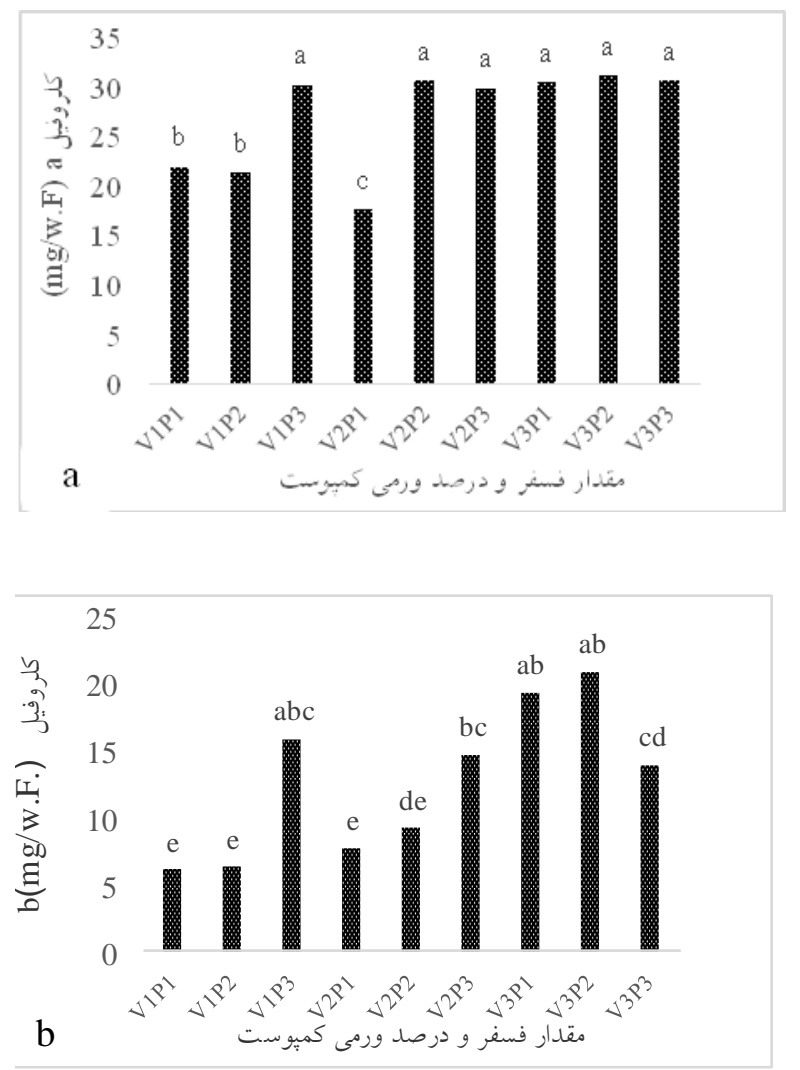

$$
\text { شكل 7- ميزان كلروفيلa (a) a كلروفيل b (b) b آهار تحت تاثير }
$$

Fig 6. Chlorophy a (a) and chlorophy b (b) production in Zinnia treated with different concentrations of phosphorus and vermicompost

بررسى طول برگ نشان داد كه اثر متقابل بستر و فسفر معنى دار نشده، اما هريكى بهتنهايى اثر معنى دارى نشان دادند. بررسى اثر ورمى كميوست حاكى از آن بود كه بيشترين

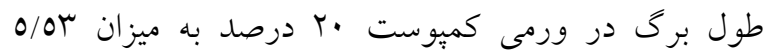

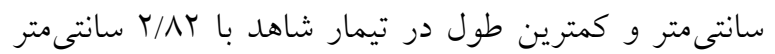
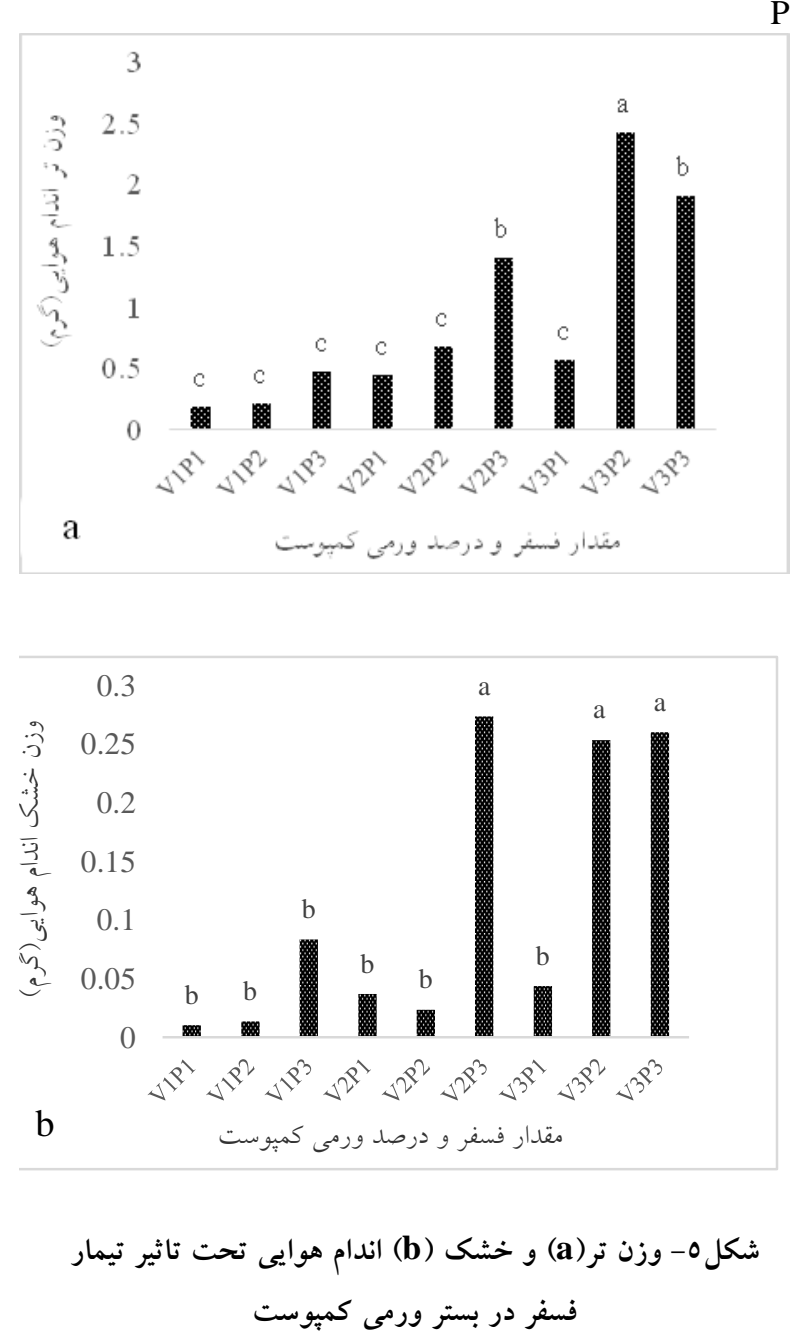

Fig 5. fresh weigth (a) and dry weight (b) plant in Zinnia treated with different concentrations of phosphorus and vermicompost

بيشترين مقدار طول ساقه گل دهنده در بستر ورمى كميوست •r درصد و فسفر ا ميلى گرم بر كيلو گرم به مقدار

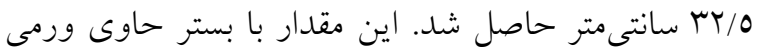
كميوست • ا درصد و فسفر ا ميلى گرم بر كيلو گرم به ميزان rV/77 سانتى متر تفاوت معنى دارى نشان نداد. كمترين مقدار نيز در بستر بدون ورمى كميوست با فسفر 10 • ميلى گرم بر كيلوگرم به مقدار ع/0 سانتىمتر بدست آمد كه با تيمار

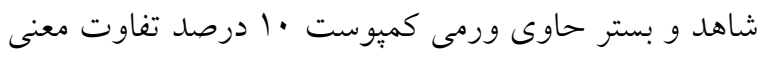
دارى نداشت (شكل a-V). حداكثر قطر كل در بستر ورمى جمى كميوست •r درصد و فسفر ا ميلى گرم بر كيلو گرم به ميزان 


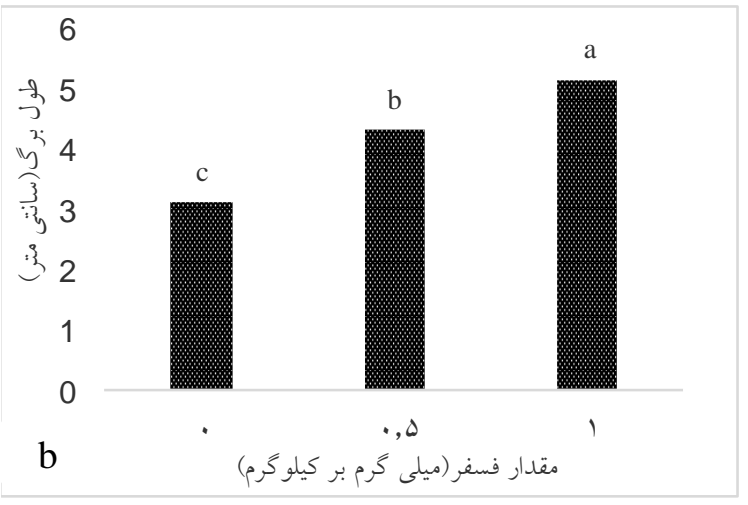

شكل ^- طول برى آهار تحت تاثير تيمار فسفر (a) و بستر ورمى

$$
\text { كميوست(b) }
$$

Fig 8. Leaf length in Zinnia treated with different concentrations of phosphorus (a) and vermicompost

(b)

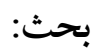

در اين يزوهش با مقايسه صفات مورفولوزى و بيوشيمايى گل آهار، مشاهده گرديد كه بيشترين ميزان يارامترهاى مورد بررسى در تيمارهاى حاوى سطوح بالاى ورمى كميوست و فسفر به دست آمد. بيشترين مقدار صفاتى همجِون قطر كل، تعداد شاخه كل دهنده، مقدار كلروفيل ها، وزنتر و خشك و شاخص سبزينگى در اين تيمارها حاصل شد كه تائيد كننده اين موضوع است كه كاربرد ورمى كميوست و فسفر باعث بهبود صفات رويشى و كلدهى مورد مطاله در اين كياه شده است. استفاده از ورمى كميوست در بستر كشت مىتواند در بهبود ساختمان خاك، افزايش نخهارى رطوبت و تأمين عناصر غذايى نقش داشته و موجب افزايش شاخص هاى رشد و عملكرد گردد.(رضايى مودب ونبوى كلات اوس|). نتايج بررسى رسولى (97r) نشان داد كه استفاده از منابع مختلف ورمى كميوست در سطوح متفاوت موجب بهبود صفات مورفولوزيك گل داوودى شده است. كاربرد ورمى كمبوست موجب افزايش عملكرد شده و نقش مهمى در جذب عناصر غذايى و كاهش آسيبهاى

$$
\begin{aligned}
& \text { حاصل شد (شكل a-1). همجِنين تيمار فسفر ا ميلى گرم بر } \\
& \text { كيلوگرم نيز بيشترين طول برگ با ل/ه سانتىمتر به دست } \\
& \text { آمد. كمترين طول برى نيز در تيمار شاهد به ميزان ع// } \\
& \text { سانتى متر مشاهده شد (شكل b-1). }
\end{aligned}
$$
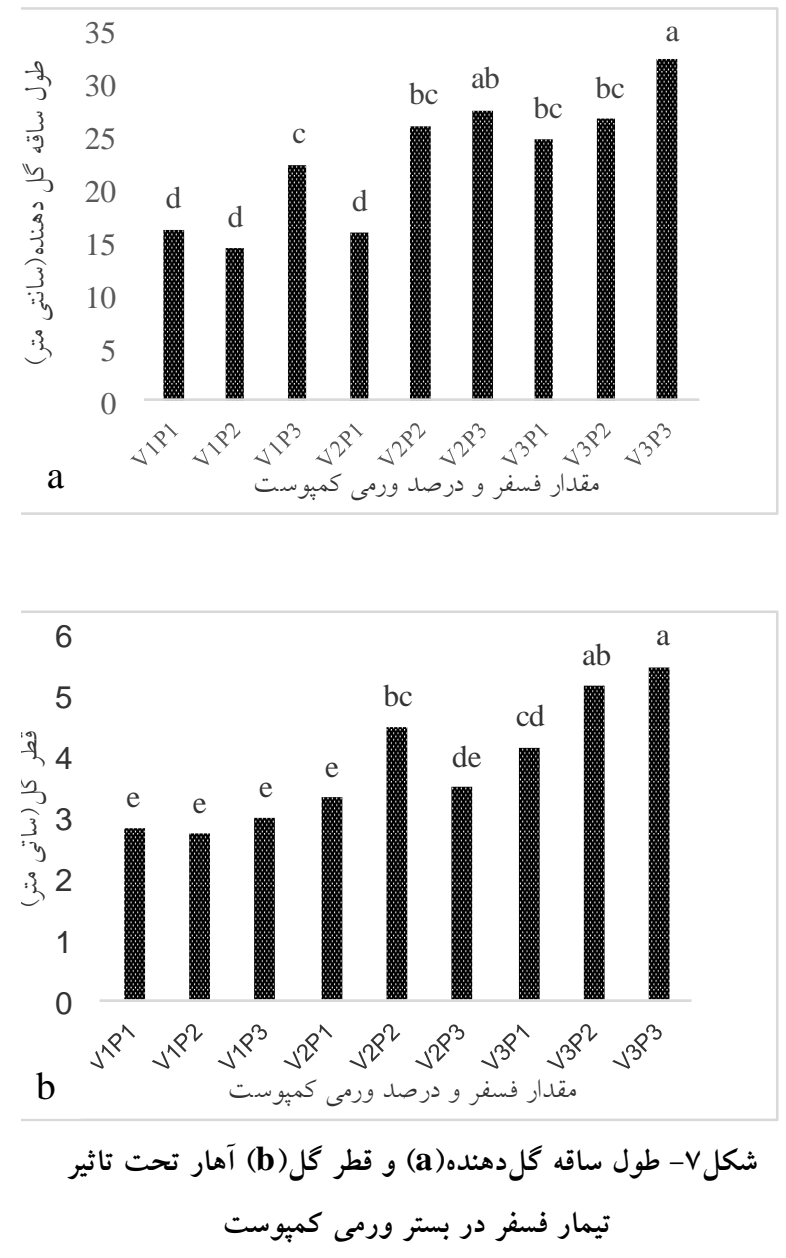

Fig 7. Flowering stem length (a) and Flower diameter (b) in Zinnia treated with different concentrations of phosphorus and vermicompost

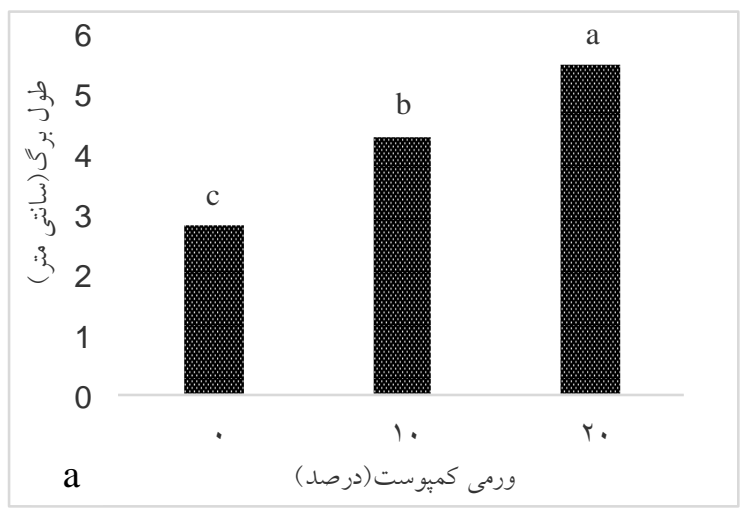


كياه ضرورى است؛ علاوه بر اين، نقش آن مربوط به دريافت، نخهارى و استفاده از انرزى است. علاوه بر اين، فسفر نقش مهمى در مورفولوزى ريشههاى جانبى و انشعابات ريشه دارد و نهتنها بر رشد ريشه، بلكه همجنين در دسترس بودن مواد مغذى اثر مى گذارد؛ بنابراين، گَياهان

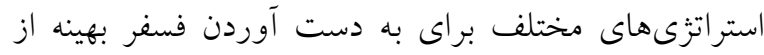

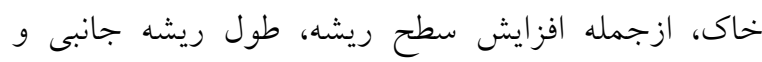

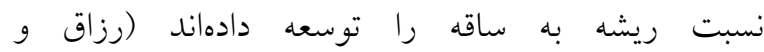

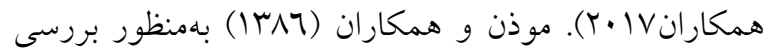
اثر تراكم بوته و سطوح مختلف فسفر بر صفات زراعى و عملكرد ميوه و دانه گياه دارويى كدوى تخم كاغذى در

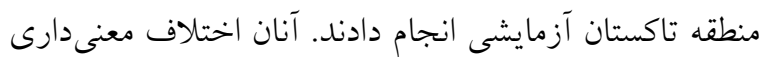
را در تعداد گره، طول بوته، تعداد برگ، وزن خشك برگ و تعداد ساقه فرعى نسبت به ساير تيمارها و تيمار شاهد مشاهده كردند. ازآنجهت كه فسفريكى از مهمترين عناصر

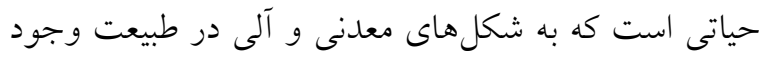
دارد، كمبود فسفر نهتنها بهشدت در ميزان رشد تأثير دارد بلكه روى تشكيل ميوه و دانه و كيفيت آنها نيز مىتواند بسيار مؤثر باشد. فسفر مىتواند بر كميت و كيفيت دانه بسيار مؤثر واقع شود. كزارشها حاكى از آن است كه استفاده از غلظت هود هاى مختلف فسفر بر تعداد گل در بوته و هم:جنين برافزايش

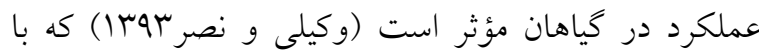
نتايج حاضر همخوانى دارد. خلوتى و همكاران (Y0.0.

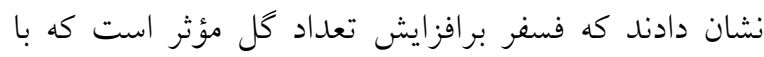
اين يزوهش مطابقت دارد. با توجه با اثر مثبت فسفر بر

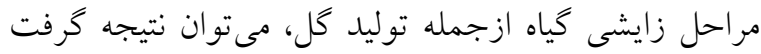
كه افزايش جذب فسفر موجب افزايش قطر كل شده است

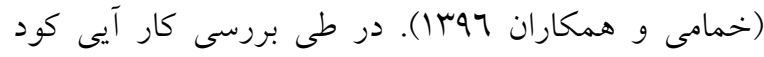

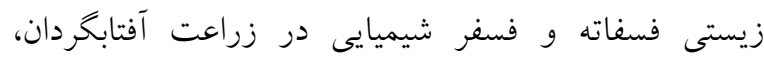
بيشترين قطر طبق گل را در تيمار فسفر زيستى به همراه

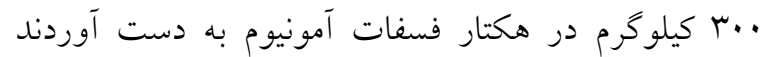

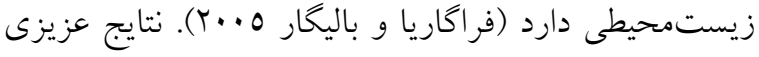

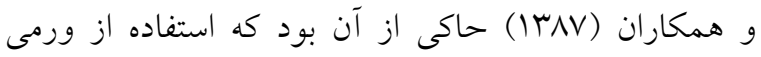
كمبوست در افزايش عملكرد كيفى بابونه نقش داشته است. بررسىها نشان مىدهد ورمى كميوست با افزايش ظرفيت

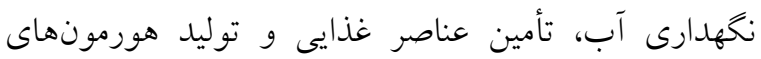

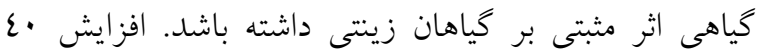
درصدى سطح برى و وزن خشى گوجهافرنكى و بهبود

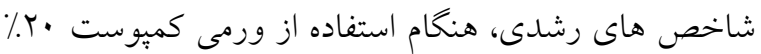

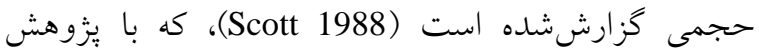
حاضر همخوانى دارد.

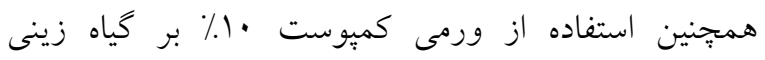
ماكنوليا موجب افزايش معنى دار وزن خشك گياه شده است (Bachman \& Davis 2000). همجنين نتايج يزوهشى نشان داد كه افزودن ·ل تا •r درصد ورمى كميوست خوكى به

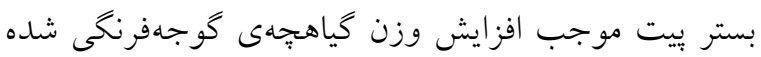

است (Atiyeh et al. 2004). عبدل و همكاران (1999) گزارش كردند كه با مصرف كميوست، عملكرد برگ و ساقه آفتابخردان بهطور معنى دارى افزايش يافت كه به دليل تجزيه مواد آلى و آزادسازى بهري تدريجى عناصر غذايى به شكل قابلجذب بـ براى كياه مىباشد. ورمى كميوست به طرق مختلفى روى رشد كياه

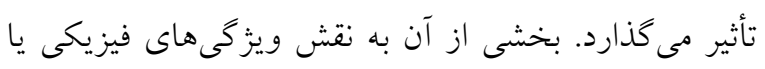

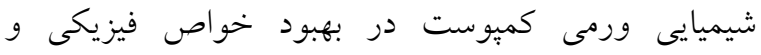
شيميايى خاك مربوط است و بخشى ديخر احتمالا ناشى از تحريك رشد به دليل افزايش فعاليت هورمونهاى كياهى بهى مانند اكسين و جيبرلين مىباشد كه به ميكروفلور همراه با ورمى كميوست مربوط است و نيز به متابوليتهايى مربوط بئ مىشود كه در اثر متابوليسم ثانويه توليد مىشوند (ادوارد و

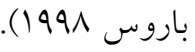
فسفر بهعنوان مواد مغذى اصلى براى رشد كياه محسوب مىشود و براى حفظ توليد و كيفيت مطلوب كياه موردنياز است. اين عنصر براى تقسيم سلولى، توليدمثل و متابوليسم 
دست آمده از آزمايش نشان مىدهد كه استفاده از ورمى

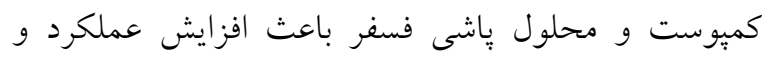
خصوصيات رويشى گياه آهار مى گردد.

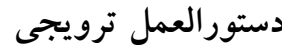

1- با توجه به اينكه استفاده از ورمى كمبوست در بستر باعث افزايش ظرفيت نخهدارى آب و تامين عناصر غذايى براى گياهان زينتى مىشود، كاربرد آن به همراه خاك در بستر كشت گل آهار در درصدهاى حجمى بـ بيش

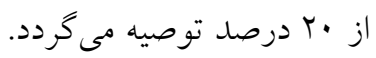

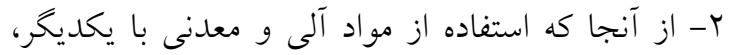
موجب افزايش كيفيت و كلدهى مى گردد، بنابراين توصيه

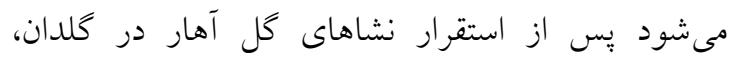

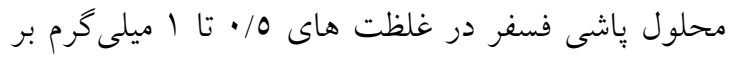
كيلو گرم انجام كيرد.

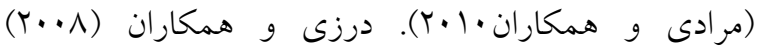
افزايش ارتفاع بوته رازيانه را با كاربرد كود زيستى فسفاته

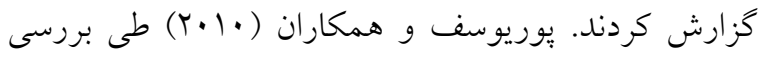
اثر تيمارهاى مختلف حاصلخيزى خاى بر كياه اسفرزه مشاهده كردند كه ارتفاع بوته بهطور معنى دارى تحت تأثير

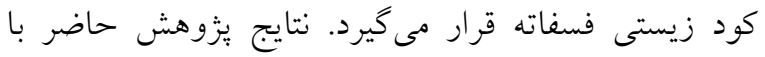

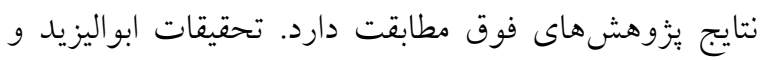

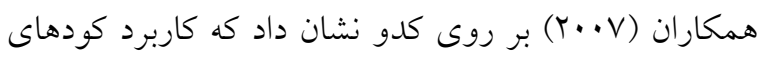
زيستى فسفاته موجب افزايش وزنتر كياه شده است. با همان توجه به نقش فسفر در حفظ و انتقال انرزى، فعاليت برخى آنزيمها، فتوسنتز، تنفس سلولى، ساخت ساكاروز و نشاسته و انتقال كربوهيدراتها قابل توجيه است. نتايج مشابهى تركي

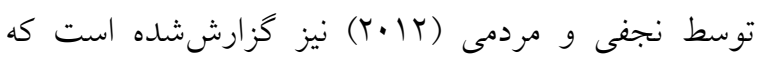
مصرف كودهاى آلى با افزايش جذب مردي عناصر غذايى و بهبود وضعيت رشد و تغذيه گياه آفتابخردان شده است. نتايج به

اسماعيلى س روحى ب شيران و محمدخانى ع (YTr|). بررسى اثرات كلريد كلسيم، هورمونهاى جيبرلين و بنزيل آدنين

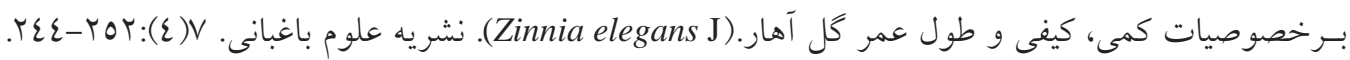
امجزى ح و حميديور م (1) (1). اثر فسفر، ورمى كميوست و زئوليت طبيعى بر خصوصيات كمى و كيفى كل آهار. علوم و

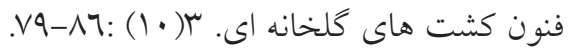
باى بوردى م و سيادت ح (ع^بr|). كشاورزى كودها و محيط زيست(ترجمه). مؤسسه انتشارات نزهت. شركت يارا اينترنشنال

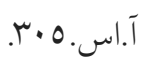

جعفرى س ر نيكخواه م زارعى غ و زارع زاده ع (ع (1)). تاثير سطوح نيتروزن و فسفر بر عملكرد تر و خشك برى و

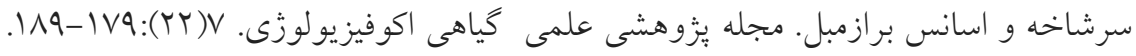

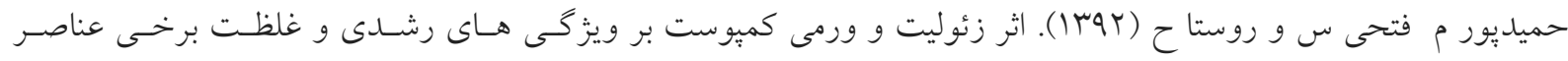

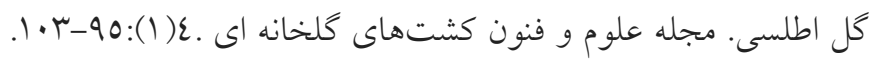

خمامى ع هاشم آبادى د برارى تاجانى ع و فلاحع (1\%7 (1). مقايسه اثر كودهاى بيولوزيكى و شيميايى فسفره بر جذب فسفر 


$$
\begin{aligned}
& \text { و عملكرد كياه زينتى هميشه بهار (Calendula officinalis). تحقيقات كاربردى خاك. 0(1):V9-99. }
\end{aligned}
$$

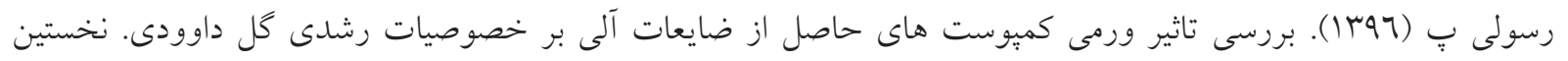

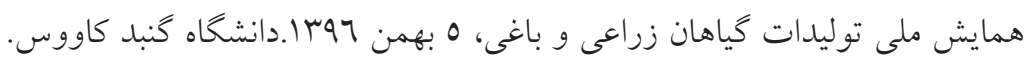

$$
\begin{aligned}
& \text { رضايى مودب ع نبوى كلات س و صدر آبادى حقيقى م ( r (Ir)). اثر ورمى كميوست و كودهاى زيستى بر عملكرد رويشى و }
\end{aligned}
$$

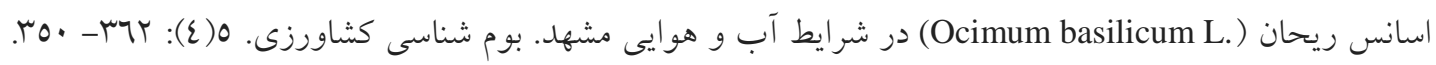

$$
\begin{aligned}
& \text { عزيزى م رضوانى ف حسن زاده خياط م لكزيان ا و نعمتى ح (IrNV) } \\
& \text { خصوصيات مورفولوزيكى و ميزان اسانس بابونه آلمانى (Matricaria recutita) رقم Goral. مجله تحقيقات گیاهان دارويى } \\
& \text { و معطر ايران. r(ع): r r }
\end{aligned}
$$

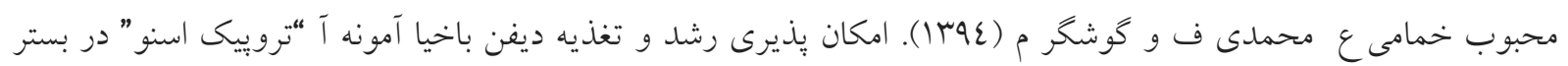

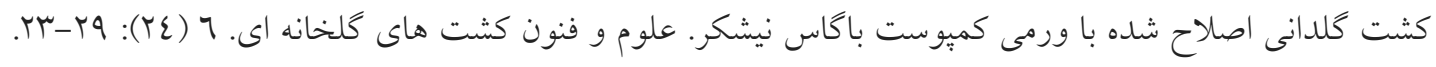

$$
\begin{aligned}
& \text { ميركوهى ع كاظمى ف بابالار م و نادرى ر (سوب(). اثر محدود سازى كاربرد فسفر در كتترل ارتفاع و بهبود كيفيت كياه }
\end{aligned}
$$

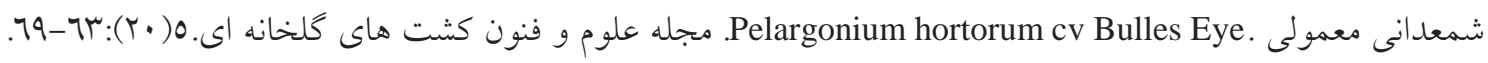

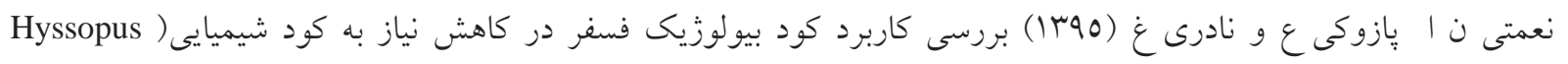

$$
\text { (r.officinalas L }
$$

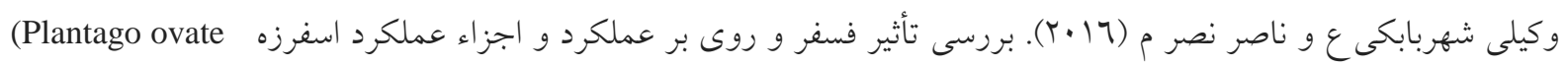

$$
\text { forsk ) }
$$

Abdel-Sabour M F, Abo El-Seoud, M A, and Rizk, M (1999). Physiological and chemicalresponse of sunflower to previous organic waste composts application to sandy soils. EgyptJ. Soil Sci. 3(9): 407-420.

Abou El-yazeid A, Abou-Aly H E, Mady M, and Moussa S A M (2007). Enhancing growth productivity dissolving microorganism (Bio-phosphor) combined with boron foliar. Agricultural and Biological Sciences. 3(4):274-286.

Ahmad H, Sajjid M, Hayat S, Ullah R, Ali M, Jamal A, Rahman A, Aman Z, and Ali, J (2017). Growth, Yield and Fruit Quality of Strawberry (Frageria ananasa Dutch) under Different Phosphorus Levels. Research in Agriculture, 2(2): p.19.

Ahmad S R, Ahmad, M Y Ashraf, M Ashraf and E A Waraich (2009). Sunflower (Helianthus annuusL.) response to drought stress at germination and seedling growth stages. Pak. J. Botany. 41(2): 647-654.

Atiyeh R M, Arancon N, Edwards C A and Metzger J D ( 2004). Influence of earth worm processed pig manure on the growth and yields of greenhouse peppers. Bioresource Technology. 9(3): 139-144.

Bachman G, R and Davis W E (2000). Growth of Magnolia virginiana liners in vermicompost - amended media. Pedo Biologia. 4(3):579-590.

Bachman C R and J D Metzger (2008). Growth of bedding plants in commercial potting substrate amended with vermicompost. Bioresour. Technol. 9(9): 3155-3161.

Darzi M, Ghalavand T A, and Rejali F (2008). Effect of mycorrhiza, Vermicompost and biological phosphate fertilizer on flowering, yield and symbiotic root, fennel medicinal plant. Journal of Crop Science. 10 (1):10988 . 
Edwards C A and I Burrows (1988). The potential of earthworm composts as plant growth media. In: Earthworms in Waste and Environmental Management, SPB Academic Publ. Co, The Hague, The Netherlands. 211-219 PP.

Gajalakshmi S, and S A Abbasi (2002). Effect of the application of water hyacinth compost/vermicompost on growth and flowering of Crossandera undolaefolia and on several vegetables. Bioresour. Technol. 8(5): 197-199.

Hashemabadi D and Zarchini M (2000). Yield and quality management of rose (Rosa hybrid cv. Poison) with plant growth regulators. Journal of Plant Omics. 3(6): 167-17.

Khalvati M A, Mozafar A, Schmidhalter U (2005). Quantification of water uptake by arbuscular mycorrhizal hyphae and its significance for leaf growth, water relations, and gas exchange of barleysubjected to drought stress. Plant Biology.1(7): 706-712.

Moazzen Sh, Daneshian J, Valadabadi S A, Baghdadi H (2007). Study of plant population and phosphate fertilization on some agronomic characters and seed and fruit yield of pumpkin (Cucurbita pepo L.). Iranian Journal of Medicina and Aromatic Plants. 22(4): 397-409.

Moradi M, Mdani H, Pilevari Khomami R (2010). The application of biological phosphorus andphosphorus chemical characteristics compared with a sunflower in Arak. Proceedings of the Eleventh Congress of Crop Science.2262 - 2265, pp.

Najafi N, Mardomi S (2012). The effects of waterlogging, sewage sludge and manure onthe growth characteristics of sunflower in a sandy loam soil. J. Water Soil. 25(6): 1264-1276. (In Persian).

Pooruosef M, Mazaheri D, Chaichi M R, Rahimi A, Tavakoli A (2010). Effects of soil fertility treatments on some morphological characteristics Agro morphologic and psyllium mucilage. Journal of Crop Production, 2(1): 21-25. (In Persian).

Razaq M , Zhang P, Shen, H L (2017). Influence of nitrogen and phosphorous on the growth and root morphology of Acer mono. PloS one. 12(2):171-321.

Samartzidis C T, Awada E, Maloupa K, Radoglou and H I A Constantinidou (2005). Rose productivity and physiological responses to different substrates for soil-less culture. Sci. Hort. 106: 203-212

Scott M A (1988). The use of worm -digested animal wastes as a supplement to peat in leas composts for hardy nursery stocks. In: Edwards, C.A.,and Neuhayser, E. (eds.) Earthworm in Waste and Enviromental Management. SPB Academic Press, Netherlands. 221-229. 


\title{
Investigating the effect of phosphorus on flowering and vegetative traits of zinnia (Zinnia sp) in vermicompost
}

\author{
Rahmani Fatemeh", mohammadi Amirali, Moradi Hosein \\ Department of Horticultural Science, Faculty of Agriculture \& Natural Resources, Sari University, Sari, Iran. \\ fatemehrahmani60@gmail.com
}

\begin{abstract}
Zinnia (Zinnia sp) has long flowering period and is used as cut flower, pot plant and landscap desings. The effect of different levels of phosphorus and vermicompost medium were studied on the vegetative and flowering characteristics of Zinna. Treatments consisted of phosphorus at three levels $(0,0.5$ and 1 $\mathrm{mg} / \mathrm{kg}$ ) and vermicompost at three levels $(0,10$ and $20 \% \mathrm{vol})$. The experiments were factorial based on a completely randomized design with three replications. Plants grown in greenhouse conditions for two months. The plants were then cut off from the crown and the leaves and stems were separated. Some of the traits measured included dry weight of the plant, chlorophyll content, vegetation index, root length, flowering stalk and flower diameter. The results showed that the use of phosphorus and vermicompost at higher levels had a significant effect the measured charcteristics. The highest diameter of flower was 5.5 $\mathrm{cm}$ and the maximum length of flowering branch was $32.5 \mathrm{~cm}$ in treatment of $1 \mathrm{mg} / \mathrm{kg}$ phosphorus and $20 \%$ vermicompost. Maximum chlorophyll a and b content, root and shoots fresh and dry weights and vegetation index were observed when vermicompost at level of $20 \%$ and phosphorus at levels of 0.5 and 1 $\mathrm{mg} / \mathrm{kg}$ were used. In general, results indicated that use of vermicompost with phosphorus spraying improved the vegetative and flowering indices.
\end{abstract}

Keywords: Culture Medium, Flower Diameter, Greenhouse, Yield, Chlorophyll. 